\title{
Institutional Advancement Activities at Select Hispanic-serving Institutions: The Politics of Raising Funds
}

Received (in revised form): April 8, 2004

\section{Michael William Mulnix}

Dr. Michael Mulnix, is Dean of Graduate Studies and Research at the University of the Incarnate Word in San Antonio, Texas. He is a founding editor of the Journal of Hispanic Higher Education (JHHE), an international refereed journal published by Sage Publications, Inc. He is also an editor of a new yearly series published by Information Age, Inc. titled Contemporary Perspectives in Hispanic and Latino Business and Education.

\section{Randall G. Bowden}

Dr. Randall Bowden, is associate dean of continuing education at Saint Leo University in Saint Leo, Florida. He is a founding editor of the Journal of Hispanic Higher Education.

\section{Esther Elena López}

Dr. Esther López, is a practicing psychotherapist and institutional consultant in San Antonio, Texas, and visiting professor of education at several universities in Mexico, as well as Visiting Assistant Professor of Psychology at the University of the Incarnate Word in Texas. She is editor of the Journal of Hispanic Higher Education and an editor of Contemporary Perspectives in Hispanic and Latino Business and Education.

\begin{abstract}
This article analyzes the current state of institutional advancement activities at Hispanic-serving institutions (HSIs) of higher education. Since the 1980s, a core group of colleges and universities in the United States with significant enrollments of Hispanic students has come to be recognized as primary providers of education to the burgeoning population
\end{abstract}

Author's Contact Address: Michael William Mulnix, Ph.D. Associate Professor of Marketing University of the Incarnate Word 4301 Broadway \#387 San Antonio, TX 78209, USA Phone: + 12108055840 Fax: + 12108053564

Email: mulnix@universe.uiwtx.edu of Hispanic students. These HSIs face a number of challenges-financial, technological and otherwise-and yet have increasing opportunities to enhance their service not only to Hispanic communities but to the nation as a whole. The funding of a majority of HSIs is closely tied to the political process. Successful lobbying efforts and the structuring of a strong advancement effort is instrumental in building healthy institutions and ensuring high graduation rates. The goal of this study was to determine what level of importance is placed on fund raising, government relations, and sponsored programs activities by CEOs at select HSIs throughout the United States. Conclusions are drawn and directions for future research are suggested. 
Keywords:

Hispanic-serving institutions, fund raising,

government relations, institutional

advancement, sponsored programs, Title $V$

\section{Overview}

Disparities in institutional advancement activities (for purposes of this study: fund raising, sponsored programs, and government relations) between Hispanicserving institutions (HSIs) and their majority counterparts are extreme. For example, a majority of HSIs are almost entirely dependent on state and federal funds and many have virtually no endowment. HSIs continue to receive far less federal funding per student on average compared with all other degree-granting institutions. Although the United States' 208 designated HSIs, which have a student enrollment that is at least 25 percent Hispanic, are at the forefront of every effort to increase Hispanic graduation rates, HSIs continue to receive only about half of the federal funding per student on average. ${ }^{1}$

Information provided by the US Department of Education shows that:

- The total revenues of HSIs are 42 percent less per FTE student than at other institutions.

- Endowment revenues at HSIs per FTE student are 91 percent less than at other institutions.

- HSIs spend 43 percent less on instruction per FTE student than other colleges and universities.

- HSIs spend 51 percent less on academic support functions per FTE than other schools.

- HSIs spend 27 percent less on student services per FTE student than other institutions. $^{2}$
According to Benitez:

It is no exaggeration to describe the financial condition of a large number of HSIs as precarious. Many HSIs are underequipped and understaffed, and they are unable to do competitive hiring, develop baccalaureate or graduate programs, maintain modern research facilities, or offer high-tech learning and working environments.

In light of these problems, some questions may be raised about the quality of instruction and the possibilities for student and faculty advancement at HSIs. Do HSIs have adequate resources to face up to the difficult task of educating a student population that lags behind in practically every academic indicator? Are Hispanic students better off at HSIs than at other institutions that are stronger financially and academically? $^{3}$

Hispanics are the fastest-growing population in the United States. While Hispanic individuals totaled a mere 3 percent of the population in 1960 (US Census Bureau statistics), the number more than quadrupled in less than three decades. According to the President's Advisory Commission, if present rates of population growth continue, by 2030 one in five persons in the United States will be Hispanic. ${ }^{4}$ Hispanic students, then, will make up 25 percent of the total school population and Hispanic youth aged five to 18 will number almost 16 million.

Benitez wrote: "Although Hispanic [individuals] are the fastest-growing minority in the United States, their numbers at all levels of the educational system in this country have not kept pace with their population growth. Dropout rates for Hispanic [students] are higher 
and dropping out occurs earlier than for most other groups." 5

Although Hispanic students have made some progress in educational achievement, they continue to trail behind the total population. For example, in 2000, the gap of high school graduation rates between white and Hispanic students aged 18-24 was almost 23 percentage points: 59.6 percent for Hispanic students compared with 82.4 percent for white students. In 2000, the college enrollment rate for white students aged $18-24$ was 43.3 percent compared with 36.5 percent for Hispanic students, a gap of 6.8 percentage points. ${ }^{6}$

During the period between 1990 and 1999, the number of Hispanic students enrolled in all institutions of higher education increased by almost 70 percent from 782,000 in 1990 to $1,317,000$ in 1999. Of the total Hispanic students enrolled in institutions of higher education in 1999, more than half $(55.8 \%)$ were enrolled in community colleges. ${ }^{7}$

Although Hispanic students represented 8.9 percent of all the students enrolled in institutions of higher education in 1999, ${ }^{8}$ they earned 8.7 percent of the associate degrees but only 5.8 percent of all bachelor's degrees, 4 percent of master's degrees, and 4.9 percent of firstprofessional degrees. ${ }^{9}$ Hispanic individuals earned 1,151 of the 41,060 doctoral degrees awarded in 1999, or 2.8 percent of all doctoral degrees. ${ }^{10}$

Only 10.6 percent of Hispanic students 25 years or older had completed four years of college in 1999, compared with 25.6 percent for all of this age group. ${ }^{11}$

The underrepresentation of Hispanic students on American college campuses and the low percentage who have earned degrees correlates with their underrepresentation in good, high paying jobs. As a consequence, the underrepresentation of Hispanic students also correlates with lower earnings. On average, non-Hispanic white men earn US\$17,000 more a year than Hispanic men, and non-Hispanic white women earn US\$6,700 a year more than Hispanic women. $^{12}$

Without question, added resources would assist HSIs to recruit and retain more students. Educated Hispanic students are key to America's future vitality. According to the Commission on Minority Participation in Education and American Life:

America is moving backward-not forward-in its efforts to achieve the full participation of minority citizens in the life and prosperity of the nation. In education, employment, income, health, longevity, and other basic measures of individual and social wellbeing, gaps persist-and in some cases are widening-between members of minority groups and the majority population. If we allow these disparities to continue, the United States inevitably will suffer a compromised quality of life and a lower standard of living. Social conflict will intensify. Our ability to compete in world markets will decline, our domestic economy will falter, our national security will be endangered. In brief, we will find ourselves unable to fulfill the promise of the American dream. ${ }^{13}$

And according to Benitez: $\ldots$ it is fair to say that HSIs as a group are presently at the front line of American postsecondary education. They are dealing with the population mix that will dominate the twenty-first century, and they appear to be doing better than any other group of institutions at meeting the educational needs of Hispanics. Whether their 
efforts and resources suffice to meet the challenge of educating Hispanic [students] in the United States is another question. HSIs at present are seriously under-funded, and most do not go beyond the undergraduate level. That is not sufficient to serve the needs of the population, or of the nation in the future. ${ }^{14}$

The gravity of the state of Hispanic higher education was spelled out in a recent Report on the White House Strategy Session on Improving Hispanic Student Achievement stating, "The urgency of these troubling gaps between Hispanic youth and their peers in educational achievement demands concerted awareness and effort because the disparities signal not just diminished possibilities for individual Hispanics, but squandered potential for the economic strength of the nation as a whole." ${ }^{\prime 15}$ This report asserted as one of its goals to "Double the percentage of Hispanic Americans who earn Associate's and Bachelor's degrees by 2010."16

Although gaps in federal funding for HSIs and historically black colleges and universities (HBCUs) has narrowed in recent years, there is still a disparity in the amount of money awarded to these two types of institutions. According to Benitez:

In the case of HBCUs, the congressional intent was to remedy past injustices and acknowledge and support the efforts of these institutions to educate blacks in the United States under very difficult conditions. Congress therefore established an entitlement program for HBCUs, with eligibility criteria including that the school be accredited and established prior to 1964 with a mission to educate black Americans. ${ }^{17}$
By law, the minimum award for an individual HBCU is $\$ 500,000$ each year. Prior to 1995, Congressional funding levels for HBCUs remained stable, at $\$ 108.9$ million while appropriations for HSIs decreased from \$12 million in 1995 to \$10.8 million in both 1996 and 1997 .

Lobbyists for Hispanic higher education gained their biggest victory to date when, in 1999, they convinced Congress to establish a separate entitlement program aimed specifically at helping HSIs. Prior to that, HSIs were grouped with HBCUs under the Title III program and competition for Congressional attention was intense. Since then, HSIs have fared much better in the Congressional arena. For example, Congress awarded HSIs $\$ 93$ million in Title V funding for FY 2003, a 7 percent increase over the $\$ 86$ million given in the prior fiscal year. The vote by House and Senate members exceeded the original White House recommendation for an $\$ 89$ million FY 2003 Title V appropriation.

Thus, from a federal funding perspective, the outlook for the nation's HSIs appears promising. Campus lobbying efforts in the nation's capital are succeeding beyond what many had forecasted. Each year, the Hispanic Association of Colleges and Universities (HACU-representing more than 300 colleges and universities serving the largest concentrations of Hispanic higher education students in the United States), holds a well-attended government relations seminar in Washington, DC and coordinates efforts by college and university presidents to lobby members of Congress. The results are, quite literally, paying off.

Title $\mathrm{V}$ remains the chief vehicle for targeting federal funds to HSIs. Under this entitlement program, HACU is requesting a $\$ 175$ million federal fiscal 
year (FY) 2004 appropriation for HSIs, as well as a first-time $\$ 20$ million federal FY 2004 appropriation for graduate education enhancements. In addition, so-called "Next Generation HSIs" legislation is proposing that a record $\$ 300$ million in federal grants be available to HSIs each year under Title $\mathrm{V}$ of the Higher Education Act (HEA), beginning in federal FY 2005. This legislation would also make it easier to apply for Title V grants by eliminating current regulatory barriers, and expand the allowable use of Title V grants. The legislation's major provisions would also:

- Eliminate the two-year wait-out period between applications by HSIs for continuing Title V grants;

- Eliminate the " $50 \%$ " low-income assurance requirement to be eligible for Title V grants;

- Expand the allowable use of Title V infrastructure grants to include articulation agreements and student support programs to facilitate the transfer from two-year to four-year institutions.

The US Senate has also endorsed legislation to help close the "digital divide" between minority and nonminority students on today's college campuses. The Digital and Wireless Network Technology Program Act, or S.196, was passed with a 97 to 0 vote. The bill would earmark $\$ 250$ million in new National Science Foundation grants each year for the next five years to HSIs and other colleges and universities serving the largest concentrations of minority students.

This brief overview brings up several interesting questions: precisely how much funding will be needed to accomplish the goal of recruiting and retaining Hispanic college and university students? And just as important, where will the money be found? The federal government can only be expected to fund up to certain levels and that, in large part, will always be influenced by politics. Money from the private sector-corporations, foundations, alumni and others-will be increasingly important to offset years of funding neglect at HSIs. With this in mind, this study set out to determine the level of support college and university presidents give to the overall institutional advancement effort in their attempt to build a solid funding base and ensure the future growth and development of their institutions.

\section{Methods and Limitations}

Little has been written on the overall subject of Hispanic higher education, and almost nothing in the area of institutional advancement at Hispanic-serving institutions. An ERIC database search conducted in January of 2002-going back to $1966-$ resulted in less than a dozen articles or chapters in books dealing with this subject. The authors therefore designed a survey to increase the field of knowledge about advancement activities at HSIs in the USA.

For purposes of this study, surveys were sent to approximately 250 college and university CEOs at HSIs who are members of the Hispanic Association of Colleges and Universities (HACU) headquartered in San Antonio, Texas. HACU-member institutions collectively enroll two-thirds of all Hispanic students in higher education and are located in 10 states comprising Arizona, California, Colorado, Florida, Illinois, New Jersey, New Mexico, New York, Texas, and Washington. Members are also located in Puerto Rico, Argentina, Brazil, Costa Rica, El Salvador, Spain, Mexico, 
Nicaragua, and Venezuela. Although institutions from these countries were surveyed, the results were not included in this particular study.

Collecting data was accomplished by utilizing bivariate and Likert scale responses on an 18-item survey. Many of the items had subcategories, for a total of 58 items. Topics related to a variety of institutional advancement issues centering around fund raising, public relations, alumni affairs, marketing, enrollment management and government relations.

For purposes of this paper, only responses related to fund raising, government relations, and sponsored programs were analyzed.

An up-to-date mailing list was obtained from HACU and a cover letter endorsing the project was written by the president of HACU. A prominent HSI university president also wrote a letter endorsing the project. The mailing took place in the spring of 2001. Follow-up e-mails were sent to encourage campus CEOs to return the surveys. Eighty completed surveys were returned for a 32 percent return rate. Data were entered in Statistical Package for Social Sciences (SPSS) for analysis. Results from the survey were calculated according to frequencies and descriptive statistics.

The primary limitation of the study is the relatively low response rate. Openended questions would have yielded rich data. This brief study, however, provides future researchers with interesting core data on which to build.

\section{The Importance of Institutional Advancement Activities}

The first question on the survey asked campus CEOs to gauge the relative importance of key institutional advancement activities on their campuses. As indicated in Table 1, the 80 college and university CEOs who responded to the survey agree overwhelmingly about the importance of these activities.

Although the numbers are perhaps too close to draw any hard and fast conclusions, it is interesting nonetheless to note that the most important advancement activity-ranked together as being either "extremely" or "very" important-is enrollment management followed by public relations, fund raising, marketing, sponsored programs, government relations, and lastly alumni relations. Conclusions likely can be drawn by the disparity of responses between, say, fund raising and alumni relations as those two advancement activities are very much interrelated. For example, the question can be asked: is it possible to have a strong

Table 1: Percent of institutional advancement activities of importance to CEOs

\begin{tabular}{llcccc}
\hline & $\begin{array}{l}\text { Not } \\
\text { important }\end{array}$ & $\begin{array}{l}\text { Somewhat } \\
\text { important }\end{array}$ & Unsure & $\begin{array}{l}\text { Very } \\
\text { important }\end{array}$ & $\begin{array}{l}\text { Extremely } \\
\text { important }\end{array}$ \\
\hline Fund raising & 0 & 8.5 & 0 & 31.9 & 59.6 \\
Alumni relations & 5.5 & 20.8 & 3.3 & 35.2 & 35.2 \\
Public relations & 0 & 1.1 & 0 & 41.8 & 57.1 \\
Government relations & 0 & 14 & 1.1 & 37.6 & 47.3 \\
Marketing & 0 & 5.4 & 4.2 & 32.3 & 58.1 \\
$\begin{array}{l}\text { Enrollment management } \\
\text { Sponsored programs (grants and }\end{array}$ & 0 & 2.1 & 2.2 & 26.9 & 68.8 \\
contracts) & 0 & 6.4 & 2.2 & 41.9 & 49.5 \\
\hline
\end{tabular}


development (fund-raising) program without a strong alumni base? In this instance, over 5 percent of campus CEOs went so far as to say that alumni relations is "not important"-the only category in the group to receive such dubious distinction-and another 21 percent to describe the activity as only "somewhat important."

It is also illuminating to find such a clear majority of CEOs indicating the importance of effective enrollment management, allowing one to hypothesize that many HSIs are almost exclusively tuition-driven and that funding from private sources has yet to supplant the importance of tuition revenue. With this in mind, it is interesting to note that government relations was listed by 14 percent of campus CEOs as being only "somewhat important" even though effective lobbying is generally seen as a way to increase state and federal revenue and to slow the mandate for hikes in tuition.

\section{Sponsored Programs}

It was originally hypothesized that a clear majority of CEOs would believe strongly in the importance of government relations and, in turn, in the importance of having an effective sponsored programs office dealing with federal and state grants as well as interacting with private foundations. A question was therefore asked: "Does your institution presently have a sponsored programs office solely responsible for (1) writing federal grants and (2) interfacing with private foundations?"

As can be seen from Table 2, approximately 70 percent of campus CEOs who responded see the importance of having sponsored programs officers who write federal grants, and 65 percent have program officers who interface with private foundations.
Table 2: Percent sponsored programs for federal grants and private foundations

\begin{tabular}{llll}
\hline & Yes & No & $\begin{array}{l}\text { Not } \\
\text { applicable }\end{array}$ \\
\hline $\begin{array}{l}\text { Federal grants } \\
\begin{array}{l}\text { Interfacing with private } \\
\text { foundations }\end{array}\end{array}$ & 64.9 & 29.8 & 1.1 \\
\hline
\end{tabular}

In an attempt to discover just how sophisticated these program officers were in monitoring federal grants and contracts, CEOs were asked if someone from their institutions regularly monitored the Federal Register and/or several well-known federal websites.

Although the data in Table 3 would indicate that a fair proportion of program officers read the Register and monitor various federal websites, it is intriguing to find that a relatively high proportion (nearly one quarter) do not. It is difficult to imagine a successful sponsored programs office not monitoring these sites. It is also highly interesting that a good number of chancellors and presidents simply "don't know" if their program officers are monitoring the sites and/or reading the Federal Register.

In an attempt to measure further the overall sophistication and effectiveness of sponsored programs offices at HSIs, the authors asked CEOs to name the type(s) of federal grants their institutions have

Table 3: Percent regularly monitoring federal websites

\begin{tabular}{llll}
\hline & Yes & No & $\begin{array}{l}\text { Don't } \\
\text { know }\end{array}$ \\
\hline The Federal Register & 71.7 & 19.6 & 8.7 \\
www.ed.gov & 60.4 & 19.8 & 19.8 \\
www.nsf.gov & 68.9 & 17.8 & 13.3 \\
Other federal websites & 69 & 17.2 & 13.8 \\
\hline
\end{tabular}


Table 4: Type of federal grant applied for in the past five years

\begin{tabular}{lllll}
\hline & $\begin{array}{l}\text { Applied for: } \\
\text { Yes }\end{array}$ & $\begin{array}{l}\text { Applied for: } \\
\text { No }\end{array}$ & $\begin{array}{l}\text { N/A } \\
\text { Don't } \\
\text { know }\end{array}$ \\
\hline FIPSE & 68.8 & 18.2 & 0 & 13 \\
Title VI (BIE) & 23.5 & 51.5 & 1.5 & 23.5 \\
Title V (ED) & 76.7 & 19.2 & 1.4 & 2.7 \\
Teacher quality enhancement (ED) & 43.1 & 44.4 & 1.4 & 11.1 \\
TOP (Commerce) & 7.2 & 67.1 & 0 & 25.7 \\
TRIO or McNair (ED) & 77.3 & 17.3 & 0 & 5.4 \\
Eisenhower (ED) & 31.6 & 40.8 & 13.3 & 14.3 \\
ESTASI (ED) & 2.9 & 56.5 & 1.4 & 39.2 \\
\hline
\end{tabular}

both applied for and received over the past five years.

As indicated in Tables 4 and 5 , the federal programs receiving the most attention from HSIs are TRIO (designed to retain and graduate low income, disadvantaged students), Title $\mathrm{V}$ (established in 2000 and targeted specifically to help HSIs), and FIPSE (the Fund for the Improvement of Postsecondary Education). Following these three, there is a significant drop-off in the amount of attention paid to other federal aid programs, particularly those outside of the Department of Education. It would appear that a majority of sponsored programs officers are concentrating primarily on ED grants.

The attention being paid, in particular, to Title V and TRIO appear to be paying off. Fully 55 percent of those institutions that have applied for a Title $\mathrm{V}$ award have received one, while over 50 percent of those applying for TRIO have been successful. Following those two programs there is, however, a significant drop-off in success rates.

It was hypothesized that many campus CEOs-believing in the importance of lobbying as a way to increase federal funding and to interact with program officers more effectively for key entitlement

Table 5: Type of federal grant received in the past five years

\begin{tabular}{lclrr}
\hline & $\begin{array}{l}\text { Received: } \\
\text { Yes }\end{array}$ & $\begin{array}{l}\text { Received: } \\
\text { No }\end{array}$ & N/A & $\begin{array}{l}\text { Don't } \\
\text { know }\end{array}$ \\
\hline FIPSE & 33.8 & 50.0 & 2.9 & 13.3 \\
Title VI (BIE) & 9.6 & 59.7 & 9.7 & 21.0 \\
Title V (ED) & 60.3 & 31.5 & 5.5 & 2.7 \\
Teacher quality enhancement (ED) & 35.3 & 45.6 & 8.8 & 10.3 \\
TOP (Commerce) & 6.2 & 58.5 & 12.3 & 23.0 \\
TRIO or McNair (ED) & 61.2 & 25.4 & 3.0 & 10.4 \\
Eisenhower (ED) & 30.3 & 50.0 & 7.6 & 12.1 \\
ESTASI (ED) & 1.7 & 55.0 & 13.3 & 30.0 \\
\hline
\end{tabular}


Table 6: Percent lobbying presence in Washington, DC

\begin{tabular}{lllll}
\hline & Yes & No & N/A & $\begin{array}{l}\text { Don't } \\
\text { know }\end{array}$ \\
\hline Percent & 45.1 & 50.5 & 2.2 & 2.2 \\
\hline
\end{tabular}

programs-would have a lobbying presence in the nation's capital. As Table 6 indicates, this is not necessarily true.

Fully 50 percent of those who responded said they do not have a lobbying presence in Washington, DC. Of those who responded that "yes" they do have a lobbying presence, it is interesting to note that only six (9.3 percent) of those who responded rely primarily on HACU, generally considered the primary "voice" of HSIs in the United States (see Table 7). What this may indicate is that HSIs remain at a disadvantage when lobbying members of Congress due to the lack of a centrally organized lobbying group. Again, however, we want to caution that a relatively low response rate ( 32 percent) could be skewing our interpretations.

\section{Fund Raising}

As previously mentioned, increases in private funding would go a long way in reducing the reliance of HSIs on tax dollars. Private money allows for a certain "margin of excellence" for state institutions and is, of course, mandatory for the survival of private schools. Our working hypothesis was therefore that college and university presidents at HSIs would put a great deal of emphasis on development/fund-raising efforts at their institutions. While this appears to be true (see Table 1) we found it highly interesting to discover that nearly 58 percent of those CEOs who responded to the survey rated their fund-raising efforts as "not very effective" or only "somewhat effective." As Table 8 shows, only 5 percent rated their efforts at raising money as "extremely effective."

In an attempt to determine the sophistication of fund-raising efforts at HSIs, CEOs were asked if they have a formal, written investment policy at their institutions. As indicated in Table 9, a sizeable majority do have just such a policy. What is surprising, however, is that fully 11 percent of those who responded said they "didn't know" if such a policy existed. And over 11 percent said they did not have a formal investment policy, leading one to question just how their endowments are being managed and what, precisely, is being said to donors and potential donors regarding the management and investment of funds.

As Table 10a indicates, over 12 percent of the CEOs said they do not employ full-time development officers at their institutions. It is logical to conclude that the same 12 percent who do not have a formal investment policy also do not employ full-time development officers; in other words, fund raising is likely nonexistent at these institutions. Of those who responded (Table 10b), a clear

Table 7: Percent of type of presence in Washington, DC

\begin{tabular}{llllllll}
\hline & $\begin{array}{l}\text { Private } \\
\text { firm }\end{array}$ & AASCU & HACU & other & AAU & NAICU & NASULGC \\
\hline Percent & 12.4 & 3.1 & 9.3 & 19.6 & 0 & 0 & 0 \\
\hline
\end{tabular}


Table 8: Percent of institution's current fund-raising efforts

\begin{tabular}{llllll}
\hline & $\begin{array}{l}\text { Not very } \\
\text { effective }\end{array}$ & $\begin{array}{l}\text { Somewhat } \\
\text { effective }\end{array}$ & Unsure & $\begin{array}{l}\text { Very } \\
\text { effective }\end{array}$ & $\begin{array}{l}\text { Extremely } \\
\text { effective }\end{array}$ \\
\hline Fund-raising efforts & 7.5 & 52.1 & 3.2 & 31.9 & 5.3 \\
\hline
\end{tabular}

Table 9: Percent of institutions with a formal written investment policy

\begin{tabular}{lllll}
\hline & Yes & No & $\begin{array}{l}\text { Don't } \\
\text { know }\end{array}$ & $\begin{array}{l}\text { Not } \\
\text { applicable }\end{array}$ \\
\hline Percent & 70.8 & 11.5 & 11.5 & 6.2 \\
\hline
\end{tabular}

majority had rather small development staffs, with over 61 percent saying they employed only one to three fund-raising officers. Four of those who responded had quite large staffs, employing over 10 fulltime development officers.

As Table 11 indicates, a majority of those who responded said the endowment at their institution was rather small; nearly 70 percent have endowments less than $\$ 15$ million. It is rather illuminating to learn that two of those who responded "didn't know" the size of their endowments indicating, again, that perhaps an endowment is nonexistent.

The growth of the endowments at many of the HSIs appears to be quite
Table 10a: Percent of employment of fulltime development/fund-raising officers

\begin{tabular}{lcc}
\hline & Yes & No \\
\hline Percent & 87.5 & 12.5 \\
\hline
\end{tabular}

Table 10b: Percent of number of full-time development/fund-raising officers

\begin{tabular}{lllll}
\hline & $1-3$ & $4-6$ & $7-9$ & $\begin{array}{l}10 \text { or } \\
\text { more }\end{array}$ \\
\hline Percent & 61.5 & 18.1 & 12.0 & 8.4 \\
\hline
\end{tabular}

healthy, as indicated in Table 12. Over 45 percent have percentage growth rates of between 5-10 percent and over 25 percent have growth rates of between 10-15 percent.

Despite what appears to be effective management of a majority of endowment

Table 11: Percent of approximate endowment size in millions of dollars

\begin{tabular}{lrll}
\hline & Percent & & Percent \\
\hline Under $\$ 1$ million & 22.6 & $\$ 25+$ to $\$ 40$ million & 5.4 \\
$\$ 1$ to $\$ 3$ million & 11.8 & $\$ 40+$ to $\$ 60$ million & 6.5 \\
$\$ 3+$ to $\$ 5$ million & 10.8 & $\$ 60+$ to $\$ 100$ million & 4.3 \\
$\$ 5+$ to $\$ 10$ million & 8.6 & Over $\$ 100$ million & 7.5 \\
$\$ 10^{+}$to $\$ 15$ million & 11.8 & Not applicable & 5.4 \\
$\$ 15+$ to $\$ 25$ million & 2.2 & Don’t know & 3.1 \\
\hline
\end{tabular}


Table 12: Percent of institutions endowment annual growth rate

\begin{tabular}{|c|c|c|c|c|c|c|}
\hline & $\begin{array}{l}\text { Less than } \\
5 \%\end{array}$ & $\begin{array}{l}5 \%+\text { to } \\
10 \%\end{array}$ & $\begin{array}{l}10 \%+\text { to } \\
15 \%\end{array}$ & $\begin{array}{l}15 \%+\text { to } \\
20 \%\end{array}$ & $\begin{array}{l}20+\% \text { to } \\
25 \%\end{array}$ & $\begin{array}{l}\text { Over } \\
25 \%\end{array}$ \\
\hline Percent & 18.7 & 46.7 & 25.3 & 5.3 & 4.0 & 0 \\
\hline
\end{tabular}

Table 13: Percent satisfied with institution's current growth rate of the endowment

\begin{tabular}{llllllll}
\hline & $\begin{array}{l}\text { Not very Somewhat } \\
\text { satisfied }\end{array}$ & $\begin{array}{l}\text { Unsure } \\
\text { satisfied }\end{array}$ & $\begin{array}{l}\text { Very } \\
\text { satisfied }\end{array}$ & $\begin{array}{l}\text { Extremely } \\
\text { satisfied }\end{array}$ & $\begin{array}{l}\text { Don't } \\
\text { know }\end{array}$ & $\begin{array}{l}\text { Not } \\
\text { applicable }\end{array}$ \\
\hline Percent & 16.7 & 28.9 & 11.1 & 25.6 & 6.7 & 4.4 & 6.6 \\
\hline
\end{tabular}

funds at these HSIs, nearly 50 percent of those college and university CEOs who responded to the survey were "not very satisfied" or only "somewhat satisfied" with the current growth rate (see Table 13). Only slightly more than 6 percent responded that they were "extremely satisfied" with the growth rate of their endowment.

Finally, CEOs were asked what was needed to make their overall advancement efforts more successful (see Table 14). A

Table 14: Percent of institutions needing to make overall advancement activities more successful

\begin{tabular}{ll}
\hline & Percent* \\
\hline Clearer goals and objectives & 34.7 \\
$\begin{array}{l}\text { Integrated advancement plan } \\
\text { Revision of organizational } \\
\text { structure }\end{array}$ & 49.5 \\
$\begin{array}{l}\text { Significant increase of } \\
\quad \text { resources }\end{array}$ & 54.7 \\
$\begin{array}{l}\text { Presidential involvement } \\
\text { More research }\end{array}$ & 20.0 \\
\hline
\end{tabular}

*CEOs could select more than one category. majority of those who responded listed "significant increase of resources" as their number-one answer, followed by development of an "integrated advancement plan."

\section{Conclusions and Recommendations}

This initial view of the current status of HSIs indicates a disjunctive approach to fund raising. Noticeably, the differences are found between what CEOs believe as important regarding fund raising and what they in turn report about actual institutional behaviors. The following conclusions and recommendations in the areas of government relations, sponsored programs, and fund raising highlight specific behaviors that may facilitate institutional advancement activities at HSIs.

\section{Government relations}

This research indicates a large portion of funding for HSIs is acquired through Title V grants. For example, close to 77 percent of the CEOs reported their institutional representatives applied for Title $\mathrm{V}$ funding which resulted in a 60 
percent success rate. One approach to increasing funding levels within individual HSIs is to increase the success rates of securing grant funding under Title V. Increasing the success rate, however, means that more money needs to be allocated each year by Congress. Without such an increase, the money per institution becomes much smaller and competition for a limited amount of dollars intensifies. With this in mind, CEOs at HSIs need to gain a greater presence in Washington, DC and significantly expand their lobbying efforts. Only 45 percent of the CEOs report a presence in Washington aligned with a lobbyist group. Of those, only 9.3 percent indicate being represented by HACU whose government relations branch advocates "serv[ing] as a conduit between HACU and HSIs and the United States Government, association for services, resources, communications, etc. that will benefit HSIs." "18 Without question, HACU maintains a valuable lobbying presence in the nation's capital and has been instrumental in securing millions of dollars in additional entitlement funding (Title V in particular). Participation by HSI campus CEOs and vice presidents in other lobbying and educational groups such as CASE, NAACP, LULAC, and La Raza can be instrumental in advancing the cause of HSIs in Washington and beyond. According to Nevárez:

I was recently asked if being an HSI has been an asset or a liability to The University of Texas-Pan American in its advancement effort; I did not hesitate to answer that I think we have definitely benefited from our status as a minority-serving institution. People recognize that the Hispanic population in this country is growing, is relatively young, and is the future workforce. The widely accepted need for a well-educated workforce will keep Corporate America interested in institutions serving the fast-growing Hispanic population. ${ }^{19}$

Lobbying efforts must be targeted at raising substantially more funds-not merely to keep pace with current projected demographic changes, but to outpace them. Keeping pace with projected demographic growth only sustains current conditions over a longer period of time. The US Department of Education reported:

[T] he total revenues of HSIs are $42 \%$ less per FTE than other institutions. For real strides to be made impacting access, programs, facilities, and working environments conducive to the greater success of HSIs, exponential funding formulas must be developed to increase funds rapidly until an adequate level of funding is achieved. Whether HSIs rely on Title $\mathrm{V}$ or other government funding sources, the message is clear: CEOs need a strong ally in lobbyists and the message of lobbyists representing CEOs is to raise the level of funding exponentially, especially given the White House emphasis on doubling the percentage of Hispanics earning associate and bachelor degrees by $2010 .^{20}$

\section{Sponsored programs}

A successful sponsored programs office can be a crucial element of any postsecondary institution as it moves toward a viable institutional advancement effort. Unfortunately, when CEOs were asked if they had an office solely dedicated to (1) writing and monitoring federal grants and (2) interfacing with state, local, and private foundations, they reported 69 and 65 percent respectively. 
However, when asked to respond to what they felt would make their overall advancement activities more successful, 55 percent of executives felt there needed to be a significant increase of resources. Clearly, then, with the need for more outside revenue, a greater percentage of CEOs should be supporting the development of a strong sponsored programs effort.

As the Hispanic community grows, the wealth surrounding the community increases as well. According to C. A. Vaquero in the Houston Business Journal, "For the first time, Hispanic Americans are accumulating significant wealth and facing complex issues such as retirement planning, estate planning and tax strategies."21

This is of major importance for HSIs. For example, endowments of the top 30 private institutions in the United States exceed $\$ 100$ billion. The top 30 public institutions exceed $\$ 30$ billion in total endowments. The average endowment per student at these institutions ranges from $\$ 22,000$ to $\$ 7.4$ million. If HSIs are to achieve similar successes, CEOs must implement long-range systematic and strategic plans for building large endowments with both private and public monies. The core of this money may likely come from an emerging Hispanic upper class. The time appears ripe for CEOs at HSIs to approach the Hispanic community and encourage individuals to invest in higher education. Vaquero continued, "Hispanic wealth has surged in the US. In fact, the growth rate of wealthy Hispanics has surpassed the growth rate of wealth in the general population. Over the past 10 years, the number of Hispanic households earning over $\$ 100,000$ a year has skyrocketed 126 percent."22 And, "Many Hispanic businesses are family owned, requiring estate planning and inheritance advice. Financing education for the next generation continues to be a high priority for these families." 23

It is important that specific campaigns be waged by HSIs for targeted funds in addition to the overall endowment: for scholarships, academic programs, chairs, research, recruiting, retention, and community partnerships. Acquiring these gifts will largely fall on the shoulders of CEOs, particularly those who have a strong commitment to increasing resources through sponsored programs. Establishing viable collaborative relationships is central to this effort. As reported earlier in this paper, of the total Hispanic students enrolled in institutions of higher education in 1999, more than half (55.8 percent) were enrolled in community colleges. ${ }^{24}$ Articulation agreements between two- and four-year institutions would thus appear to be fertile ground for long-term collaborative agreements. For example, it is well known by advancement professionals that jointly authored grants-say, between community colleges and doctoral-granting institutions-are highly appealing to most federal agencies, allowing them to serve multiple constituencies. A viable sponsored programs office can be instrumental in tracking such opportunities.

\section{Fund raising}

Our research discovered that over 59 percent of CEOs felt their institution's fund-raising efforts were not as effective as they could be. This further exacerbates the problem of accessing grants and obtaining additional resources. To say that fundraising efforts at HSIs is bleak may be an overstatement; however, it would appear from our data that CEOs at these institutions have a large task ahead of them. For example, given that only 37 
percent of executives rated their institution's fund raising efforts as "effective" and given that approximately 30 percent stated that their institution either "does not have" an actual investment policy or that they do not even know if they have such a policy, the situation appears quite serious. Unless campus CEOs themselves become intimately involved in fund raising and establish it as a campus priority, it is likely the fund-raising office will continue to receive poor performance marks.

Nevárez states:

Although we were depending on the new vice president for institutional advancement to develop the organizational structure and operating guidelines, I knew that the president had to provide the leadership for the overall effort-both on and off campus. Although the chief advancement officer and other members of the development staff are certainly key to the cultivation process and work hard to develop relationships with foundations, corporations, and individuals, the president of the university is expected to be there when it is time to share the mission and vision of the institution and to show support for the individual projects. $^{24}$

\section{Directions for Future Research}

Results from this brief survey reveal that college and university CEOs at HSIs across the United States believe in the importance of fund raising, government relations, and sponsored programs. However, the majority report that their own institutional efforts in these three key areas are not entirely satisfactory. One of the most illuminating discoveries is that a large number of campus chief executives at these HSIs do not strongly believe in the importance of alumni relations in the overall advancement effort. The fact that enrollment management is listed by most as the most important of all advancement activities indicates that the raising of outside money via grants, contracts and fund raising lags behind tuition as the primary concern of most CEOs. HSIs, therefore, remain predominantly "tuition driven."

As noted, limitations of the study include a return rate of less than 50 percent and also the effect of volunteerism (the sample collected may or may not represent the target population). Future researchers will therefore find it worthwhile to take this primary data and expand upon it. Qualitative data would also enrich the information obtained about institutional trends in institutional advancement at HSIs.

\section{References}

1. G. Salas (2003), June: Notes from Washington. Hispanic Association of Colleges and Universities <http://www.hacu.net/capitol_connections/grnews>, 3, accessed July 22, 2003.

2. U.S. Department of Education (1998), "Fact sheet: Title III institutions,” Government Printing Office, Washington, DC.

3. M. Benitez (1998), "Hispanic-serving institutions: Challenges and opportunities," in J. P. Merisotis and C. T. O’Brien (eds.), Minority-Serving Institutions: Distinct Purposes, Common Goals, Jossey-Bass, San Francisco, pp. 57-68 (quote p. 61).

4. President's Advisory Commission on Educational Excellence for Hispanic Americans (1996), Our Nation on the Fault Line: Hispanic American Education. Government Printing Office, Washington, DC.

5. Benitez, "Hispanic-serving institutions," op. cit., p. 58.

6. W. B. Harvey (2002), Minorities in Higher Education 2001-2002: Nineteenth Annual Status Report, American Council on Education, Washington, DC, pp. 47-8.

7. Ibid., p. 55 .

8. Ibid.

9. Ibid., pp. 62-3.

10. Ibid., p. 75 .

11. Ibid., p. 54.

12. A. P. Carnavale (1999), Education = Success: Empowering Hispanic Youth and Adults, Educational Testing Service, Princeton, NJ. 
13. Education Commission of the States (1988), Onethird of a Nation, A report of the Commission on Minority Participation in Education and American Life,American Council on Education, Government Printing Office, Washington, DC, p. 1.

14. Benitez, "Hispanic-serving institutions," op. cit., p. 64.

15. US Department of Education (2001), Report on the White House Strategy Session on Improving Hispanic Student Achievement <http://www.ed.gov/offices/ OIIA/Hispanic/report2001jan/report2001Jan.doc>, Achievement Academic Gaps section, 1, accessed January 23, 2002.

16. Ibid., Challenging the Nation section, 6 .

17. Benitez, "Hispanic-serving institutions," op. cit., p. 64.

18. Hispanic Association of Colleges and Universities (2003), About Government Relations <http:// www.hacu.net/capital_connections/index.shtml $>$.
19. M. A. Nevárez (1997), "Successful fund raising at a university serving Hispanics," in F. H. T. Rhodes (ed.), Successful Fund Raising for Higher Education. American Council on Education, Oryx Press, Phoeniz, AZ, pp. 105-17 (quote p. 113).

20. US Department of Education, op. cit., Challenging the Nation section, 6 .

21. C. A. Vaquero III (2003), "Financial services firms target growing market of wealthy Hispanics," Houston Business Journal, August $11<\mathrm{http}: / /$ houston.bizjournals.com/houston/stories/2003/08/ 11/focus10.html>, 2.

22. Ibid., 4.

23. US Department of Education, op. cit., Financial Needs section, 1 .

24. Harvey, Minorities in Higher Education 2001-2002, p. 55.

25. Nevárez, "Successful fund raising at a university serving Hispanics," op. cit., p. 112.

\section{Practitioner's Perspective}

By 2060, Hispanics, blacks, and Asians are projected to account for 49.9 percent of the USA's population. In South Florida, we are already there. According to the latest data from the US Census Bureau, 57.3 percent of Miami-Dade County's population is of Hispanic or Latino origin and 50.9 percent of the total population was born outside of the United States. Thus Miami reflects the face of the "new" America. As such, we understand that the country is looking to us to see how we address issues like higher education for minority students-particularly Hispanics, the fastest-growing segment of the population.

While the University of Miami fits the definition of Hispanic-serving institutions28 percent of our undergraduate students are Hispanic-we are not typical of the HSIs presented in this paper. Unlike most HSIs, which the authors state are largely dependent on state and federal funding, the University of Miami has received no federal funding to date as a direct result of its HSI status. (However, with new federal funding vehicles, such as Title $\mathrm{V}$, we will be pursuing federal grants to enhance educational opportunities for all minority students.)

I agree strongly with the sentiment that fund raising, government funding, and sponsored programs are particularly critical for HSIs. Despite the challenges that many HSIs face in developing these three areas, it is imperative that they formulate and implement strategic plans embracing each of these funding sources.

It is also important that HSIs depend less on government support and more on fund raising from private contributors. Funding from the private sectorcorporations, foundations, alumni and other donors-must be a component of the HSI's overall strategic plan. These plans must identify criteria for effective fund raising, including the cultivation and stewardship of donors. At the University of Miami, we have yearly fund-raising plans and goals for an advancement staff who work hand-in-hand with our president, Donna Shalala, to bring in about $\$ 100$ million in private gifts each year. 
To cement our position as a leading research institution, the University of Miami recently launched a $\$ 1$ billion campaign to enhance academic programs, improve ties to our alumni and the South Florida community, construct state-of-the-art facilities, retain and recruit outstanding faculty, and attract top students. These are among the very things the authors cite as fund-raising targets for HSIs. I would argue that all institutions of higher education should focus on these essential aspects of a great university. But for fund raising to be successful, it must be part of a larger vision-a vision that is articulated by the institution's CEO and that has the buy-in of its governing board and other constituencies, including donors, alumni, and faculty.

A strategic plan for alumni participation is also vital for HSIs, particularly in light of the enhanced financial status of Hispanics. I was somewhat surprised to see in the results of the survey that many of the CEOs did not find alumni participation to be important. Donations and support by alumni in government and community relations are vital and can translate into concrete benefits for the institution. The alumni strategy should also include the enhancement of student life. Research has shown that there is a direct correlation between the experience students have on campus and their propensity to give as alumni.

It is important for CEOs at HSIs to develop "out of the box" initiatives that support minority graduation, including partnerships with other institutions. At the University of Miami, we are working closely with local two-year colleges-also HSIs-in fields such as engineering, to encourage minority students to earn a bachelor's degree.

With constant changes in federal funding, one of the most important things a practitioner should take away from this article is the importance that must be placed on fund raising from the private sector for all institutions of higher learning, but above all for HSIs. It is particularly important for HSIs to find greater balance between private sector revenue and government funding. While the development of a consistent flow of private sector fund raising is not accomplished overnight, it is essential that a comprehensive strategic plan for private fund raising be developed. Without it, the financial viability of continuing to serve minority students could become more precarious in the future.

Sergio M. Gonzalez Vice President for University Advancement, University of Miami, Florida, USA 